\title{
Optimalisasi Interpersonal Communication Account Officer Dalam Meningkatkan Volume Nasabah Pada Perbankan Syariah
}

\author{
Suparwi \\ Institut Agama Islam Negeri Kudus \\ parwiarif@gmail.com
}

\begin{abstract}
Competition of financial institutions is so tight, however the development of sharia banking the longer shows that the positive trend cann't be separated from the role of account officers who are important marketing figures in providing information and education to the society. Banks as financial institutions that produce financial services desperately need account officers to introduce the advantages of Sharia Banks such as mudhorobah financing, salam, Istishna' and other products such as wadi'ah, ijarah, wakalah, kafalah, hawalah, rahn, assharf and qard.

The interpersonal ability of the communication account officer is a necessity that must always be improved considering that the spearhead of banking is in the hands of the account officer. An Account Officer (AO) must be able to attract prospective customers by optimizing interpersonal communication skills with good so that customers are interested in using Sharia Bankproducts. By optimizing the interpersonal communication capabilities possessed by account officers, of course, it will be able to influence customers and create demand to for Shariah Bank products.
\end{abstract}

Keywords: Interpersonal Communication, Account Officer and Sharia banking

\begin{abstract}
Abstrak
Persaingan lembaga keuangan yang begitu ketat namun perkembangan perbankkan syariah yang semakin lama menunjukkan trend positif tidak bisa di pisahkan dari peran serta account officer yang merupakan sosok marketing penting dalam memberikan informasi dan edukasi terhadap masyarakat. Informasi dan edukasi terhadap prodak-prodak bank syariah sangat diperlukan bagi nasabah untuk bahan pertimbangan dalam proses pengambilan keputusan menentukan pembiyayaan usahanya. Bank sebagai lembaga keuangan yang menghasilkan jasa keuangan sangat membutuhkan account officer untuk memperkenalkan keunggulan dari bank syariah seperti pembiyayaan mudhorobah, salam, Istishna' dan prodak-prodak lainnya seperti wadi'ah, , ijarah, wakalah, kafalah, hawalah, rahn, as-sharf, dan qard.

Kemampuan interpersonal communication account officer merupakan keniscayaan yang harus selalu di tingkatkan mengingat ujung tombak perbankan salah satunya berada di tangan account officer. Seorang account officer $(A O)$ harus mampu menarik calon nasabah dengan bagaimana mengoptimalisasikan kemampuan interpersonal communication dengan baik sehingga nasabah tertarik untuk menggunakan prodak-prodak bank syariah. Dengan optimalisasi kemampuan interpersonal communication yang dimiliki account officer tentunya akan mampu mempengaruhi nasabah dan menciptakan permintaan atas prodakprodak bank syariah.
\end{abstract}


Optimalisasi Interpersonal Communication Account Officer Dalam Meningkatkan Volume Nasabah Pada Perbankan Syariah

Kata kunci: Interpersonal Communication, Account Officer dan Perbankan Syariah

\section{PENDAHULUAN}

Dalam kehidupan sehari-hari, setiap orang tidak dapat dilepaskan dari dunia komunikasi, mulai dari bangun tidur hingga akan tidur kembali. Dalam dunia bisnis yang bersekala kecil, menengah, maupun besar, orangorang yang berkecimpung di dalamnya tidak dapat lepas dari kegiatan komunikasi. Oleh sebab itu komunikasi merupakan faktor yang sangat penting demi pencapaian tujuan organisasi. Diantara banyaknya komunikasi maka komunikasi antar pribadi (interpersonal communications) tidak dapat dilepaskan dengan dunia komunikasi (Djoko Purwanto, 2010:26). Para profesional sukses kenapa mampu sukses dalam bidang bisnis mapun bekerja di perusahaan dikarenakan terampil dalam berkomunikasi baik orang-orang di dalam mapupun luar perusahaan.

Interpersonal communication adalah komunikasi yang di lakukan antara seseorang dengan orang lain dalam suatu masyarakat atau organisasi (bisnis dan non bisnis) dengan media tertentu dan bahasa yang mudah di pahami untuk mencapai tujuan tertentu (Djoko Purwanto, 2010:26). Dengan bahasa yang lain interpersonal communication adalah komunikasi tatap muka yang antara komunikator dan komunikan berhadap-hadapan atau betemu langsung. Dengan kemampuan berkomunikasi yang efektif, dapat mampu memperkuat hubungan antara perusuhaan dan seluruh pemaangku kepentingannya, kelompok yang berhubungan dengan aktivitas perusahaan yakni pelanggan, karyawan, pemegang saham, pemasok rekan perusahaan, komunitas dan negara (L Bovee and John V. Thill, 2013:4).

Accont officer merupakan petugas yang bekerja di sebuah perusahaan di bagian perkreditan yang peranannya sangat urgen dalam pemasaran dan pembiyayaan di lembaga keuangan. Jusuf Jopie menjelaskan istilah account officer didefinisikan sebagai aparat manajemen yang di tugaskan untuk membantu direksi dalam menangani tugas-tugas, khususnya yang menyangkut bidang marketing dan pembiyayaan (Jusuf Jopie, 1997: 8). Account officer (AO) merupakan karyawan yang bertugas untuk mencari nasabah yang layak sesuai dengan kreteria peraturan bank, menilai, mengevaluasi dan mengusulkan besarnya kredit yang diberikan (Ega Sri Dini Dan Mareta Kemala Sari, 2013:60).

Pesatnya perkembangan di dunia perbankan syariah di tanah air, khususnya dari sektor pembiyayaan disebabkan semakin gencarnya informasi dan edukasi yang diterima oleh masyarakat. Salah satu faktor terakomodirnya keperluan akan informasi dan edukasi mengenai produkproduk dari pembiyayaan bank syariah tersebut adalah dengan adanya upaya untuk memiliki sumber daya insani yang memiliki kemapuan 
komunikasi pada sektor pembiyayaan ini. Disinilah kemampuan interpersonal communication sangat di perlukan dan di optimalkan agar mampu mempengaruhi masyarakat untuk menarik calon nasabah dengan menggunakan cara yang bisa memenauhi kepuasan calon nasabah. Dengan semakin banyaknya nasabah mengambil kredit maka memungkinkan perbankkan memperoleh banyak keuntungan.

Perbankan syariah mempunyai fungsi sebagai lembaga perantara (Intermediary institution) yang menghimpun dana dari masyarakat dan menyalurkannya kembali untuk masyarakat. Atau menurut Neni Sri Imaniyati perbankan syariah merupakan lembaga perantara dari pihak yang yang memiliki kelebihan dana (Surplus Of Funds) dengan pihak yang kekurangan dana (Lock Of Funds), memiliki fungsi sebagai perantara keuangan masyarakat (Financial Intermediary) (Nani Sri Imaniyati, 2010:2).

Indonesia, sebagai mayoritas yang penduduknya islam maka diharapkan munculnya perbankan syariah yang islami menjadi alternatif bagi masyarakat untuk memilih pembiyayaan yang memberikan solusi alternatif dalam menghindari dan menjauhi praktik riba dan gharar. Gagasan ekonomi islam dimaksudkan sebagai alternatif terhadap ekonomi kapitalis dan sosialis yang bukan saja tidak sejalan dengan ajaran islam, tapi juga gagal memecahkan problem ekonomi untuk dunia ketiga. Sistem ekonomi islam diharapkan mampu mencegah terjadinya ketidakadilan dalam penerimaan dan pembagian sumber-sumber materi agar dapat memberikan kemaslahatan pada semua manusia dan memungkinkan mereka menjalankan kewajiban kepada Allah dan masyarakat.

Kegiatan usaha yang di lakukan oleh perbankan syaraiah sebagaimana di atas, bank syariah mendapatkan income atau penghasilan berupa margin keuntungan, bagi hasil, fee (ujroh) dan pungutan lainnya seperti biaya administrasi. Meskipun demikian, dari berbagai kegiatan usaha tersebut, pendapatan bank syariah sebagian besar masih berasal dari imbalan (bagi hasil/margin/fee). Imbalan tersebut diperoleh bank syariah dari kegiatan usaha berupa pembiyayaan. Karenanya, pembiyayaan masih merupakan kegiatan paling dominan pada bank syariah (Ahmad Syakir, 2014:87).

Begitu pesatnya pertumbuhan perbankan syariah tidak akan lepas dari kemampuan interpersonal communication account officer untuk memperkenalkan berbagai prodak-prodak yang di miliki sehingga nasabah memahami dan tertarik untuk menggunakannya. Bank syariah sebagai lembaga keuangan yang menghasilkan jasa keuangan sangat membutuhkan peran account officer dalam mengkomunikasikan dan memasarkan produknya. Disini optimalisasi kemampuan interpersonal comunication sebagai seorang account officer sangat diperlukan untuk 
Optimalisasi Interpersonal Communication Account Officer Dalam Meningkatkan Volume Nasabah Pada Perbankan Syariah

memperkenalkan berbagai prodaknya baik berkaitan dengan tabungan, giro, rekening koran dan lain-lain dalam meningkatkan jumlah nasabah.

\section{KAJIAN LITERATUR \\ Pengertian Account Officer}

Istilah account officer pada perbankan syariah dimungkinkan tidak asing lagi oleh sebagian orang yang bersinggungan dengan lembaga keuangan. Karena di setiap lembaga keuangan pastinya ada account officernya. Account officer merupakan karyawan yang berada di lembaga keuangan yang mengurusi dalam bidang pembiyayaan. Banyak tokoh yang mendefinisikan berbeda-beda dalam menterjemahkan pengertian makna account officer. Namun pada dasarnya adalah merupakan petugas yang bersinggungan dengan marketing.

Ahmad Subagyo dan Budi Purnomo (2009:21) Account officer adalah istilah yang diberikan kepada pegawai (staff) bank yang bertugas melayani nasabah baik nasabah yang menyimpan dananya di Bank maupun nasabah yang menggunakan fasilitas kredit dari Bank tersebut. Sumber lain menjelaskan bahwa account officer adalah petugas yang melakukan pemasaran pembiayaan, kemudian melakukan analisis pembiayaan (Zainal Arifin, 2010: 101). Namun demikian Ada beberapa bank yang menggunakan istilah berbeda tapi maksudnya sama. Account officer yang bertugas untuk memasarkan produk kredit/pembiayaan disebut dengan Loan Officer (LO), account officer yang hanya bertugas untuk mencari nasabah penabung/deposan disebut dengan Fund Officer (FO), sedangkan account officer yang bertugas memasarkan produk Bank, baik Loan maupun Funding bisa disebut Sales Officer (SO).

Seorang account officer mengawalinya membuat perencanaan, usaha apa saja yang layak dibiayai di wilayahnya, dan berapa kira-kira dana yang diperlukan untuk menyalurkan pembiayaannya, kemudian account officer akan melakukan kunjungan ke usaha nasabah, melakukan wawancara, menggali sebetulnya apa yang dibutuhkan nasabah tersebut sehingga dapat membuat suatu keputusan, apakah permohonan pembiayaan yang diajukan oleh calon debitur atau debitur yang pantas untuk dibiayai, diperlukan seorang account officer untuk melakukan probing agar kebutuhan pinjaman memang sesuai dengan keperluan nasabah. Account officer juga sekaligus menjadi konsultan, karena bagi nasabah kecil tak jarang mereka dapat bercerita, menunjukkan bon-bon, bukti penjualan atau pesanan, tetapi tidak bisa membuat laporan keuangan. Di sini account officer memandu nasabah agar dapat membuat neraca perkiraan usaha nasabah. Serta cash flow kemampuan membayarnya. Account officer juga harus sensitif, apakah nasabah mengatakan yang sebenarnya (di sinilah perlunya probing, cek dan re-cek), kemudian 
melakukan analisis, selanjutnya account officer mengusulkan dalam bentuk memorandom analisis pembiayaan kepada atasannya, dan atasannya akan meneruskan kepada komite pembiayaan (loan comitte) untuk mendapat keputusan apakah berupa persetujuan atau penolakan (Zainal Arifin, 2010: 102).

Account officer adalah seorang businessman yang bertugas mewakili bank dalam melakukan transaksi dengan nasabahnya, sebagai seorang businessman yang baik, maka seorang account officer harus bisa memahami dan tepat dalam mengambil keputusan, kapan harus melakukan bisnis, kapan tidak melakukan bisnis, dan kapan harus melakukan bisnis sedikit saja. Anda harus dapat membaca keadaan, sebagai seorang pengusaha, anda tidak akan jual rugi. Negosiasi merupakan bagian yang tidak terpisahkan dari bagian proposal kredit, seperti tingkat suku bunga pinjaman, biaya-biaya kredit dan lain-lain (Jusuf Jopie, 1995: 281)

Account officer merupakan point of contact antara pihak bank dengan nasabah yang wajib memelihara hubungan dengan nasabah, seorang account officer wajib memonitoring seluruh kegiatan nasabah secara terus-menerus (Rivai H. Veithzal, 2006: 293). Dan tentunya account officer mampu memiliki interpersonal communication yang baik agar kepuasan dan loyalitas nasabah akan terus terjaga.

\section{Peran Dan Fungsi Account Officer}

Dalam melakukan tugasnya seorang account officer memiliki fungsi ganda, di satu pihak, ia merupakan personil bank yang harus bekerja di bawah peraturan dan tujuan bank, sehingga dapat memberikan hasil (target revineu), kepada bank. Dipihak lain, ia dituntut untuk memberikan yang terbaik bagi nasabahnya, maka dari itu seorang account officer dituntut untuk mengoptimalkan kedua sisi tersebut, apabila bank memiliki seorang account officer yang berkualitas serta professional, serta memiliki interpersonal communication yang bagus maka akan sangat membantu dalam menghadapi persaingan-persaingan di dunia perbankan. Lebihlebih akan berdampak meningkatkan jumlah nasabah yang di miliki perbannkan syariah.

Adapun peranan seorang account officer pada umumnya sebagai berikut (Jusuf Jopie, 1995:8):

1. Mengelola Account

Seorang account officer berperan untuk membina nasabah agar mendapatkan efisiensi dan optimalisasi dari setiap transaksi keuangan yang dilakukan tanpa meninggalkan tanggung jawabnya sebagai personil bank.

2. Mengelola Produk 
Optimalisasi Interpersonal Communication Account Officer Dalam Meningkatkan Volume Nasabah Pada Perbankan Syariah

Seorang account officer harus mampu menjembatani kemungkinan pemakaian berbagai produk yang paling sesuai dengan untuk kebutuhan nasabahnya.

Contoh misal produk dari lembaga keuangan syariah ialah: produk alwadiah, murabahah, istishna, salam, ijarah, mudharabah, musyarakah, wakalah, kafalah, hawalah, rahn, as-sharf, dan qard.

3. Mengelola Kredit

Seorang account officer berperan untuk melakukan pemantauan atas pinjaman yang diberikan kepada nasabah agar nasabah selalu memenuhi komitmen atas pinjamannya. Untuk melaksanakan hal ini, seorang account officer harus memiliki pengetahuan tentang bisnis nasabahnya.

4. Mengelola Penjualan

Seorang account officer pada dasarnya ujung tombak bank dalam memasarkan produknya, maka seorang account officer juga harus memiliki salesmanship yang memadai untuk dapat memasarkan produk yang ditawarkan.

5. Mengelola Profitability

Seorang account officer juga berperan dalam menentukan keuntungan yang diperoleh bank, dengan demikian ia harus yakin bahwa segala hal yang dilakukannya berada pada suatu kondisi yang memberikan keuntungan pada bank.

Berikut merupakan alat analisis yang di gunakan account officer dalam pengambilan keputusan untuk memberikan pembiyayaan terhadap nasabahnya diantaranya adalah sebagai berikut yang biasa di sebut $5 \mathrm{C}$ :

1. Character, bertujuan untuk mengetahui sifat/karakter calon nasabah. Karakter ini menjadi bagian yang penting demi kelancaran kredit selanjutnya, karena karakter yang baik berdampak pada kepatuhan dalam membayar angsuran kredit nantinya.

2. Capacity, untuk mengetahui kemampuan nasabah dalam menjalankan usahanya dan proses pengembalian pembiayaan.

3. Capital, bertujuan mengetahui kebutuhan modal kerja yang diperlukan nasabah.

4. Condition, bertujuan untuk mengetahui kondisi usaha atau prospek kedepan, dan

5. Collateral, untuk mengetahui nilai jaminan atau agunan yang ditawarkan apakah telah menutupi dari jumlah pembiayaan.

\section{Definisi, proses dan bentuk communication}

Komunikasi adalah proses pemindahan pengertian dalam bentuk gagasan atau informasi dari seseorang ke orang lain (Hani handoko, 1997: 272). Proses pemindahan dari pengertian tersebut melibatkan lebih dari 
sekedar kata-kata yang digunakan dalam percakapan, akan tetapi juga ekspresi wajah, intonasi, titik putus vokal dan sebagainya. James A. F. Stoner mendefinisikan komunikasi adalah proses dengan mana berusaha memiliki pengertian yang sama lewat transmisi dari pesan-pesan simbolik (James A. F. Stoner, 1986: 146). Newman dan Summer (1961) dalam Amirullah dan Haris Budiono komunikasi adalah proses pertukaran fakta, ide, opini, atau emosi melalui kata-kata, surat-surat, simbol-simbol atau pesan (Amirullah dan Haris Budiono, 2004:282). Dari beberapa definisi sebagaimana tersebut dapat disimpulkan bahwa komunikasi merupakan sebuah proses pertukaran akan informasi dan arti.

Adapun proses komunikasi paling sederhana melibatkan domiandomain yang saling berhubungan. Model yang paling sederhana dari proses komunikasi adalah sebagai berikut: pengirim (sender) dilanjutkan pesan (message) di lanjutkan sampai pada penerima (receiver) (James A. F. Stoner, 1986: 146). Model ini menunjukkan tiga elemen penting dari komunikasi jelaslah jika salah satu elemen ini hilang, tidak akan terjadi komunikasi. Hal ini di contohkan, jika kita mengirim pesan tetapi jika tidak didengar atau diterima oleh seseorang maka tidak akan ada komunikasi yang terjadi. Sebagaimana Bovii dan V. Thill diantara penghalang komunikasi adalah kebisingan dan gangguan, pesan yang bersaing, filter dan kerusakan saluran (L Bovee and John V. Thill, 2013:14-15). Sedangkan Djoko purwanto diantara penghambat atau kesalahpahaman dalam komunikasi diantaranya ketidakmampuan dalam mengembangkan pesan, ketidakmampuan dalam menyampaikan pesan, kesalahpahaman dalam menerima pesan dan kesalahpahaman dalam menafsirkan pesan. Diantara kesalahpahaman dan ketidakmampuan tersebut dikarenakan perbedaan latar belakang, perbedaan penafsiran kata dan perbedaan reaksi emosional (Djoko Purwanto, 2010:17).

Menurut Bovee dan Thill dalam buku business communication proses komunikasi terdiri dari 6 (enam) tahap, yaitu (L Bovee dan John V. Thill, 2013:13):

1. Pengirim mempunyai ide atau gagasan

2. Pengirim mengubah ide menjadi suatu pesan

3. Pengirim menyampaikan pesan

4. Penerima menerima pesan

5. Penerima menafsirkan pesan

6. Penerima memberi tanggapan dan mengirim umpan balik kepada pengirim.

Proses komunikasi yang di lakukan harus berjalan dengan lancar agar memastikan komunikasi bisa berjalan dengan baik. Disini kemudian komunikasi di bagi menjadi 2 bentuk diantaranya adalah (Djoko Purwanto, 2010:6): 
Optimalisasi Interpersonal Communication Account Officer Dalam Meningkatkan Volume Nasabah Pada Perbankan Syariah

1. Kominikasi verbal (verbal communication)

Yaitu komunikasi melalui kata-katabaik lisan atau tertulis. Komunikasi verbal adalah komunikasi yang lazim di gunakan dalam dunia bisnis untuk menyampaikan pesan-pesan bisnis kepada pihak lain baik secara tertulis (written) maupun lisan (oral). Adapun berikut bentuk diantara komunikasi verbal yakni berbicara dan menulis, mendengar dan membaca.

2. Komunikasi non verbal (nonverbal communication)

Yaitu komunikasi yang menggunakan bahasa badan atau tubuh, seperti halnya gerakan tangan, jari, mata, kepala dan warna serta lain sebagainya. Adapun ciri-ciri komunikasi non verbal diantaranya adalah menggunakan bahasa isyarat, ekspresi wajah, sandi, simbolsimbol, pakaian seragam, warna dan intonasi suara

\section{Perbankan syariah}

Lembaga keuangan menurut SK Menku RI No. 792 tahun 1990, lembaga keuangan adalah semua badan yang kegiatannya bidang keuangan, melakukan penghimpunan dan penyaluran dana kepada masyarakat terutama guna membiyayai investasi perusahaan (Y Sri Susilo, 2000:2). Syarif wijaya mendefinisikan lembaga keuangan adalah lembaga yang berhubungan dengan penggunaaan uang dan kredit atau lembaga yang berhubungan dengan proses penyaluran simpanan ke investasi. Lembaga keuangan biasanya memberikan pembiyayaan atau kredit kepada nasabah dan menanamkan dananya dalam dalam bentuk suratsurat berharga (Syarif wijaya, 2000:6). Kasmir mendefinisikan lembaga keuangan adalah setiap perusahaan yang bergerak di bidang keuangan, menghimpun dana, menyalurkan dana atau kedua-duanya (Kasmir, 2002:2). Diantara sub-bagian dari lembaga keuangan adalah perbankkan syariah. Dengan demikian bank syariah adalah bank yang aktifitasnya meninggalkan maslah riba. Bank islam atau bank syariah adalah bank yang beroperasi dengan tidak mengandalkan pada bunga (Muhammad, 2005:13).

Bank syariah merupakan lembaga keuangan yang berfungsi memperlancar ekonomi di sektor riil melalui aktivitas kegiatan usaha (investasi, jual beli atau lainnya) yang berdasarkan prinsip syari'ah yaitu aturan perjanjian berdasarkan hukum islam antara bank dan pihak lain untuk menyimpan dana atau pembiyayaan kegiatan usaha atau kegiatan lainnya yang sesuai dengan nilai syariah, baik yang bersifat makro maupun mikro (Ascarya, 2008:3).

Bank syariah bukan sekedar bank bebas bunga, tetapi juga memiliki orientasi pencapaian kesejahtraan. Secara fundamental terdapat beberapa karakteristik bank syariah (Andri Soemitra, 2010:67): 
1. Penghapusan riba

2. Pelayanan kepada kepada kepentingan publik dan merealisasikan sasaran sosio-ekonomi islam

3. Bank syariah bersifat universal yang merupakan gabungan dari bank komersial dan bank investasi

4. Bank syariah melakukan evaluasi yang lebih berhati-hati terhadap permohonan pembiyayaan yang berorientasi kepada penyetoran modal, karena bank syariah menerapkan profit and loss sharing

5. Bagi hasil cenderung mempererat hubungan anara bank syariah dan pengusaha

Pembiyayaan merupakan salah satu produk perbankan syariah yang paling penting dalam perkembangan perbankan syariah di indonesia. Dalam menyalurkan dana pada nasabah, secara garis besar produk pembiyayaan syariah terbagi kedalam tiga kategori yang di bedakan berdasarkan tujuan penggunaannya yaitu (Ahmad syakir, 2014:89)

1. Transaksi pembiyayaan yang ditujukan untuk memiliki barang dilakukan dengan prinsip jual beli. Diantaranya adalah pembiyayaan murabahah, salam, istisna'

2. Transaksi pembiyayaan yang ditujukan untuk mendapatkan jasa dilakukan dengan prinsip sewa (ijarah). Pada dasarnya prinsip ijarah sama dengan prinsip jual beli, namun perbedaannya terletak pada objek transaksinya.

3. Transaksi pembiyayaan untuk usaha kerjasama yang di tujukan guna mendapatkan sekaligus barang dan jasa, denga prinsip bagi hasil. Diantara pembiyayaan yang berasakan bagi hasil adalah musyarokah, mudharabah muqoyyadah meliputi hiwalah, rahn (gadai), qardh, wakalah, kafalah.

\section{PEMBAHASAN}

\section{Optimalisasi Interpersonal communication account officer dalam meningkatkan volume nasabah}

Lembaga keuangan syariah yang dalam hal ini salah satunya adalah perbankan syariah, baik milik negara maupun swasta sebagai suatu pelaku ekonomi yang tidak lepas dari kondisi globalisasi. Era globalisasi yang sedang berkembang saat ini memiliki suatu dampak dalam suatu persaingan dunia termasuk dalam dunia bisnis. Sebagai konsekuensi logis dari timbulnya persaingan yang semakin tajam dan kompleks, ada tiga kemungkinan yang terjadi pada lembaga keuangan yaitu mundur, bertahan atau tetap unggul dan bahkan semakin berkembang. Proses kemungkinan tersebut memungkinkan manajemen melakukan kebijakankebijakan dalam pengambilan keputusan antara lain adalah meningkatkan kemampuan sumber daya yang dimiliki. Gary Desseler menjelaskan 
Optimalisasi Interpersonal Communication Account Officer Dalam Meningkatkan Volume Nasabah Pada Perbankan Syariah

perubahan yang sangat cepat mengharuskan perusahaan untuk lebih kompetitif, lebih cepat dan responsif, lebih efektif biaya, lebih ilmiah dalam cara mereka mengambil keputusan dan yang tidak kalah penting adalah harus berorientasi modal manusia (Gary Desseler, 2015:11).

Orientasi modal manusia menjadi keharusan yang harus di lakukan oleh lembaga keuangan khususnya bagi petugas bank (account officer). Sehingga kemampuan sumber daya manusia yang dimiliki akan lebih memiliki kompetensi baru, motivasi yang tinggi dan beretika yang baik. Dalam praktik di lapangan seorang account officer merupakan faktor sentral atau bisa di katakan ujung tombak bank syariah dalam memasarkan produknya, lebih-lebih prodak-prodak bank syariah selama ini masyarakat masih belum mengetahui betul informasi yang utuh tentang prodak yang di miliki bank syariah. Maka seorang account officer harus memiliki kemampuan komunikasi diantaranya adalah interpersonal communication untuk menjual (Salesmanship) dan melakukan pemantauan atas pembiyayaan yang diberikan kepada nasabah agar nasabah tersebut memenuhi kuwajiban pembayaran serta mampu menjaga hubungan baik dengan nasabah agar tetap menjadi nasbah yang mempergunakan prodak yang di miliki bank syariah.

Interpersonal communication account officer seharusnya selalu di tingkatkan supaya lebih meningkatkan layanan pelanggan sebuah bank syariah. Pengembangan komunikasi antar pribadi atau komunikasi tatap muka sangatlah penting bagi account officer, karena mengelola hubungan baik dan memberikan pemahaman yang luas kepada nasabah serta edukasi tentang prodak-prodak bank syariah merupakan bagian yang utama demi kelancaran dan kesuksesan perbankkan. Account officer merupakan poin of contact antara bank dengan pihak costemer yang senantiasa harus memelihara hubungan baik dengan nasabah dan wajib memonitoring seluruh kegiatan nasabah secara terus menerus.

Optimalisasi kompetensi interpersonal communicatian account officer bukan hanya menjadikan bertambahnya volume anggota perbankan namun mampu mendatangkan efektifitas yang lebih besar diantaranya sebagaimana Amirullah dan Haris adalah mampu melihat nasabah dengan tepat sebagai dasar pengambilan keputusan pemberian kredit, membawa orang-orang yang terlibat dalam lembaga perbankan untuk lebih meningkatkan motivasi untuk menghasilkan kinerja yang lebih baik mengingat keputusan pemberian kredit melibatkan berbagai devisi dan yang tidak kalah penting adalah menjadikan untuk mengerti perlunya perubahan (Amirullah dan Haris Budiono, 2004:282)

Optimalisasi interpersonal communication oleh account officer dapat mampu menyampaikan informasi kepada nasabah dengan akurat dan saling membutuhkan akan informasi yang di sampaikan dan dimiliki 
sehingga nasabah memahami betul tujuan account officer, selain itu interpersonal communication dapat saling membagi pengalaman kepada orang lain mengenai prodak dan perbankkan syariah secara umum, dan optimalisasi interpersonal communication account officer mampu menumbuhkan simpati sehingga nasabah memiliki ketertarikan akan prodak yang di miliki pihak bank. rasa simpati ini adalah sikap positif yang ditunjukkan oleh seorang yang muncul dari lubuk hati yang paling dalam untuk ikut merasakan apa yang di rasakan oleh komunikatorn (Djoko Purwanto, 2010:27). Ini artinya bagaimana perbankkaan syariah merupakan solusi yang tepat bagi keputusan pendanaan bagi nasabah sebagai keputusan dari dalam individu untuk lebih meminimalisir riba.

Tidak hanya disitu optimalisasi interpersonal communication account officer mampu melakukan kerjasama antara seseorang dengan orang lain untuk mencapai tujuan tertentu atau untuk melakukan sesuatu yang bermanfaat bagi kedua belah pihak dan umpan balik yang diperoleh untuk segera di respon (Hani Handoko, 1997:275). Ini artinya kemungkinan bagaimana nasbah tertarik untuk mengambil pinjaman di tempat account officer bekerja. Melalui interpersonal communication account officer dapat memotivasi orang lain untuk melakukan sesuatu yang baik dan positif (Djoko Purwanto, 2010:27). Ini artinya nasabah dengan adanya pertemuan dengan account officer mampu tumbuh untuk termotivasi meminjam di bank dalam rangka pemperluas usaha dan memperluas modal yang dimiliki

\section{KESIMPULAN}

Perkembangan lembaga keuangan yang semakin kompetitif dan banyaknya lembaga keuangan baik konvensional maupun syariah yang berdiri serta memperluas cabangnya. Mengharuskan perbankkan syariah untuk melakukan berbagai cara agar perusahaan mampu bertahan dan selalu tumbuh berkembang seiring dengan perubahan ruang dan waktu yang berbeda. Perubahan ini tentunya harus di respon baik oleh manajemen dengan bagaimana meningkatkan kualitas kemampuan account officer di perbankan syariah. Mengingat peran dan fungsi account officer sangat urgen dan bisa di bilang merupakan ujung tombak perbankan syariah dalam pembiyayaan dan faktor penentu keberhasilan dalam membina dan memikat nasabah baik nasabah baru maupun nasabah lama, maka account officer dituntut memiliki kemampuan interpersonal communibcation yang bagus.

Interpersonal communication account officer menjadi keharusan yang harus selalu di optimalisasikan guna meningkatkan hubungan baik dengan nasabah serta dapat mampu meningkatkan volume nasabah baru di perbankan syariah yang pada akhirnya akan meningkatkan profitabilitas 
Optimalisasi Interpersonal Communication Account Officer Dalam Meningkatkan Volume Nasabah Pada Perbankan Syariah

perusahaan. Dengan optimalisasi interpersonal communication yang di miliki account officer tentunya akan mampu menemukan dan memberikan kredit kepada nasabah dengan kualifikasi dan persyaratan layak untuk di berikan dan kemungkinan terjadi kredit macetnya rendah. Serta dengan optimalisasi interpersonal communikasi account officer mampu memberikan informasi-informasi yang utuh terhadap prodak-prodak bank syariah yang selama ini masih ada sebagian banyak masyarakat belum mengetahui.

Optimalisasi kemampuan interpersonal communication account officer mampu mempengaruhi dan menumbuhkan motivasi calon nasabah yang pada akhirnya menentukan untuk menggunakan prodak-prodak bank syariah. Selain itu optimalisasi kemampuan interpersonal communication account officer mampu menjadi penjebatan hubungan baik yang saling menguntungkan antara nasabah dengan pihak perbankan. Nasabah bisa mendapatkan fasilitas kredit dari bank dan pihak bank dapat bagi hasil serta membantu menumbuhkan perekonomian.

\section{DAFTAR PUSTAKA}

A. Wangsawidjaja Z (2012), Pembiayaan Bank Syariah, Jakarta: PT. Gramedia Pustaka Utama.

Ahmad Subagyo dan Budi Purnomo,(2009), Account Officer Commercial Microfinance, Yogyakarta: Graha Ilmu

Ahmad syakir, Peran Account Officer Dan Perkembangan Pembiyayaan Pada Perbankan Syariah, Jurnal MADANI vol.XVIII, NO.1, Juni 2014

Amirullah dan Haris budiono, (2004), Pengantar Manajemen, Yogyakarta: Graha Ilmu.

Andri Somitra,(2010), Bank Dan Lembaga Keuangan Syariah, Jakarta: Kencana Prenada Media Group.

Ascarya, (2008), Akad Dan Praktik Bank Syariah, Jakarta: PT Raja Grafindo Persada.

Courtland L. Bovee dan John V. Thill, (2012), Komunikasi Bisnis Edisi 9, Jakarta; Indeks

Djoko Purwanto,(2011) Komunikasi Bisnis, Jakarta: Erlangga

Ega Sri Dini Dan Mareta Kemala Sari, Pengaruh Latar Belakang Pendidikan Dan Pelatihan Terhadap Kinerja Account Officer (Ao) Kridit Komersial Bank Bri Sumatra Barat, Jurnal EKONOMICA Vol. 2 No. 1, 2013

Gary Desseler, (2015), Manajemen Sumberdaya Manusia, Jakarta: Salemba Empat.

Hani Handoko, (1997), Manajemen Edisi 2, Yigyakarta: BPFE.

James A.F. Stoner, (1986), Manajemen, Jakarta: Erlangga.

Jusuf Jopie, (1997), Panduan Dasar Untuk Account Officer, Yogyakarta: YKPN. 
Kasmir, (2002), Bank Dan Lembaga Keuangan Lainnya, Jakarta: PT Raja Grafindo persada.

Muhammad, (2005), Bank Syariah; Problem Dan Prospek Perkembangan Di Indonesia, Yogyakarta: Graha Ilmu.

Muhammad, (2005), Manajemen Bank Syari'ah, Yogyakarta: UPPAMPYKPN.

Neni Sri Imaniyati, (2010), Pengantar Hukum Perbankkan Indonesia, Bandung: Refika Ditama.

Y Sri Susilo, dkk,(2000) Bank Dan Lembaga Keuangan Lain, Jakarta: Salemba Empat.

Zaenul Arifin, (2010), Dasar-dasar Manajemen Bank Syari'ah, Bandung: Alvabet. 